\title{
Polycyclic Aromatic Hydrocarbons in Weihe River, a Typical River in Arid and Semi-Arid Region of Northwest China: Trends of Pollution and Risk
}

\author{
Yuyun Chen ${ }^{1,2 *}$, Yanxia Dong ${ }^{1}$, Ting Duan ${ }^{1}$, Junqin $Z^{2} a^{1}{ }^{1}$, Yiqiang Zhou ${ }^{1}$ \\ ${ }^{1}$ College of Water and Environment, Chang' an University, Xi'an, China \\ ${ }^{2}$ Key Laboratory of Subsurface Hydrology and Ecology in Arid Areas, Ministry of Education, Xi' an, China
}

Received: 9 April 2020

Accepted: 1 July 2020

\begin{abstract}
The distribution, source and potential ecosystem risk of 16 priority polycyclic aromatic hydrocarbons (PAHs) in Weihe River were estimated. In 2015 the mean values of $\sum$ PAHs were $278.4 \mathrm{ng} / \mathrm{L}$ in water dissolved phase (WDP) and 1,340 ng/g dry weight (dw) in sediment, respectively. While in 2016 the mean concentrations of $\sum$ PAHs reduced to $108.6 \mathrm{ng} / \mathrm{L}$ in WDP and $539.1 \mathrm{ng} / \mathrm{g} \mathrm{dw}$ in sediment, respectively. The concentrations of PAHs in Weihe River were at a moderate level compared with other rivers in the world. Compared with the data in our previous study in 2014 and the data in other studies, the PAHs level in Weihe River in 2015 and 2016 decreased obviously. The PAHs concentrations in WDP and sediment samples from 8 sewage outlets discharging into Weihe River were much higher than those in Weihe River. Principal component analytical results indicated that coal combustion was the most important source of PAHs in Weihe River. The results suggested that Weihe River Comprehensive Treatment Project (WRCTP) played its role effectively in reducing PAHs pollution of Weihe River.
\end{abstract}

Keywords: polycyclic aromatic hydrocarbons, distribution, source, Weihe River, risk, arid and semi-arid region

\section{Introduction}

Polycyclic aromatic hydrocarbons (PAHs) are a widespread class of compounds with two or more aromatic rings containing solely hydrogen and

*e-mail: chenyuy@chd.edu.cn carbon [1]. These compounds can be introduced into the environment through various routes and are ubiquitous in the environment. Both anthropogenic activities and natural emissions are the PAH sources of coastal sediments. Anthropogenic sources include petrogenic and pyrolytic PAH contaminations. Due to their persistent, toxic, genotoxic and carcinogenic characteristics and potential human health risk, sixteen PAHs were designated as priority pollutants and seven 
PAHs were designated as potentially carcinogenic pollutants by USEPA.

Perennial rivers are major sources of freshwater for aquatic ecosystems worldwide. PAHs from a variety of sources (i.e. run-off, wet and dry deposition) end up in the riverine environment and many eventually accumulate in sediments. For the above reasons, PAHs' level, transport, fate, sources and environmental risk in river systems have become an advanced research hotspot in environmental fields all over the world. A lot of papers have reported on PAHs in rivers, including Tiber River (Italy) [2], Sarno River (Italy) [3], Prai and Malacca Rivers (Malaysia) [4], Zarqa River (Jordan) [5], Mahakam River (Indonesia) [6], Moscow River (Russia) [7], Inner Clyde Estuary (UK) [8], Delaware River Estuary (USA) [9], Poxim River (Brazil) [10] and Hooghly and Brahmaputra Rivers (India) [11].

During the last several decades, China has experienced great economic development, resulting in an immense increase in petroleum hydrocarbon consumption, which results in vast input of PAHs to environment inevitably. Rivers have been an important carrier of PAHs. Many papers have reported on PAHs in rivers in China [12-20]. However, most of these rivers studied were located in the humid and semi-humid regions. Due to relatively lower population density and underdevelopment, very few studies on PAHs in rivers in the arid and semi-arid regions of Northwest China were published [21-23].

Xi'an city, the capital city of Shaanxi Province located in Northwest China, is known as the starting point of the ancient Silk Road and one of the ancient capitals of the world's four major civilizations. It has a population of more than 10,000 thousand inhabitants and an area of $10108 \mathrm{~km}^{2}$. The car ownership of Xi'an City at the end of 2015 was more than 2,300,000 based on the data from Xi'an Police Station. Weihe River is a typical river in arid and semi-arid regions and is the mother river of Shaanxi Province. Weihe River and its branches have been seriously polluted by Chemical Oxygen Demand (COD) [24]. Some PAHs concentrations in Weihe River were very high [21-22]. With the rapid increase in population and economic wealth, the insufficient water supply and degradation of water environment has become one of the most restrictive factors for Weihe River basin's economic development. So Weihe River Comprehensive Treatment Project (WRCTP) has been carried out since 2008 by Shaanxi provincial government. As a whole, the mean values of COD have decreased slightly in recent years based on the data from Shaan'xi Province Environmental Protection Agency, while in some sections of Weihe River the COD values have increased in reverse. A decrease in COD does not mean a decrease in PAHs concentration, since PAHs contribute little to the COD value. These changes of PAHs level in Weihe River have not been estimated during the process of WRCTP.

In this study, we have therefore investigated the occurrence and level of PAHs in the surface water and riverine sediment in Weihe River in 2015 and 2016. Further, principal component analysis (PCA) were used to estimate distribution and source apportionment in order to better assess the potential ecological risks due to PAHs contamination. At last, the concentration change of the sixteen PAHs in water and sediments with the implementation of WRCTP was analysed by comparing result in this study with data from the

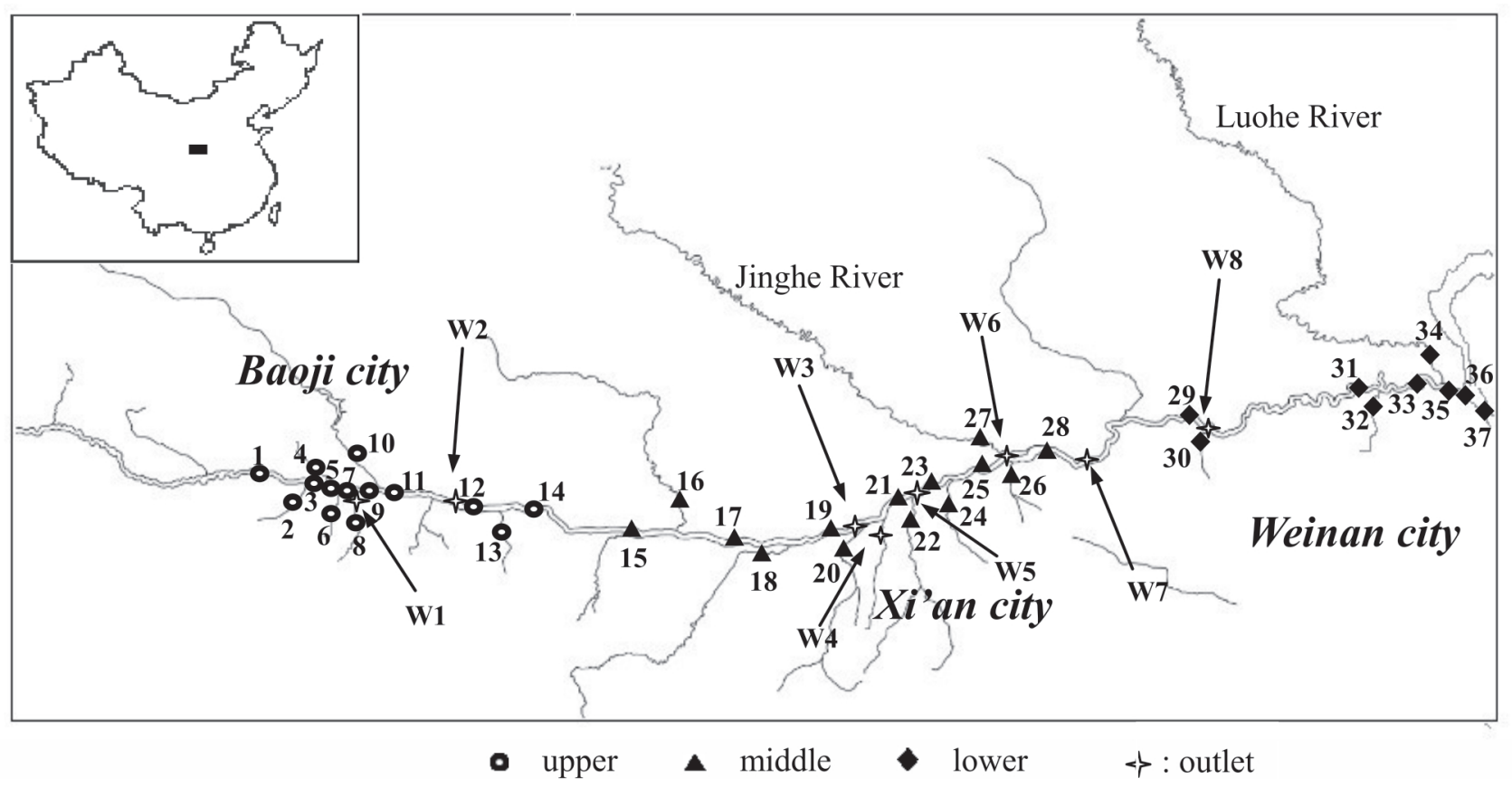

Fig. 1. The study area and sampling locations. 
literature. The results would be useful to understand PAHs pollution in rivers in the arid and semi-arid regions.

\section{Materials and Methods}

\section{Study Area and Sampling}

Weihe River is a typical river located in arid and semi-arid region in Northwest China. With a length of $818 \mathrm{~km}$, it is an important water resource for industrial production, agricultural irrigation and community livelihood.

Thirty-seven sampling sites along Weihe River and its tributaries were selected (Fig. 1). Samples were collected on 29-31 August 2015 and 29-31 August 2016, respectively. In 2016, other 8 water samples (W1 to W8) and 4 sediment samples (W1 to W4) in sewage outlets discharging into Weihe River besides the 37 sites were collected. During the whole sampling process, global position system (GPS) was used to locate the sampling stations.

In each sampling site, water samples were taken from $50 \mathrm{~cm}$ below the surface level with $2.0 \mathrm{~L}$ brown glass bottle. Water samples were filtered through a previously kiln-fired $\left(400^{\circ} \mathrm{C}\right.$ overnight $) \mathrm{GF} / \mathrm{F}$ glass fiber filter (47 $\mathrm{mm} \times 0.7 \mu \mathrm{m}$; Whatman, Maidstone, UK) in laboratory. Water dissolved phase refers to the fractions of contaminants passing through the filter. These filtrates were kept in the dark at $4^{\circ} \mathrm{C}$ and extracted within 24 hours. Surface sediment $(0-5 \mathrm{~cm})$ samples were collected by using a grab sampler (Van Veen Bodemhappe $2 \mathrm{~L}$ capacity) and put in aluminum containers. The sediments were transported refrigerated to the laboratory and kept at $-20^{\circ} \mathrm{C}$ before analysis.

\section{Chemicals and Instruments}

The following 16 PAHs were used for quantitation: naphthalene (NAP), acenaphthene (ACE), acenaphthylene (ACY), fluorene (FLU), phenanthrene (PHE), anthracene (ANT), fluoranthene (FLU), pyrene (PYR), benzo[a]anthracene (BaA), chrysene (CHR), benzo[b]fluoranthene $(\mathrm{BbF})$, benzo[k]fluoranthene $(\mathrm{BkF})$, benzo[a]pyrene $(\mathrm{BaP})$, dibenzo[a,h]anthracene (DhA), benzo[g,h,i]perylene (BgP) and indeno[1,2,3c,d]pyrene (IcP), which were from AccuStandard, Inc. (New Haven, KY, USA). All solvents used were HPLC grade or equivalent. The water used was purified by milli-Q Ultra-pure Water Purifier (Millipore, Mass., USA). The total organic carbon (TOC) of sediment was determined by TOC analyzer (TOC-VCPH; Shimadzu Corp., Shimadzu, Japan).

An Agilent 6890A gas chromatography-5975C ion trap mass spectrometry (GC/MS) system equipped with a DB-EUPAH $(20 \mathrm{~m} \times 0.18 \mathrm{~mm} \times 0.14 \mu \mathrm{m})$ capillary column (Agilent Technologies, Palo Alto, CA, USA) was used in this study. High-purity helium (He) was used as carrier gas. The injection port temperature was maintained at $270^{\circ} \mathrm{C}$. The column temperature was programmed as follows: started at $60^{\circ} \mathrm{C}$ and held for $1 \mathrm{~min}$; then increased at a rate of $11^{\circ} \mathrm{C}$ per minute to $270^{\circ} \mathrm{C}$; and finally ramped to $300^{\circ} \mathrm{C}$ at $1.5^{\circ} \mathrm{C} / \mathrm{min}$ and held for $2 \mathrm{~min}$. The analysis was performed using the selected ion monitoring (SIM) mode with a splitless injection. Target analytes were identified and verified by comparing retention times of the samples with standards and using the characteristic ions and their ratio for each target analyte. The RSDs of retention time for 16 PAHs were all below than $0.5 \%$.

\section{PAHs Extraction}

A Solid phase extraction (SPE) cartridges system from Supelco (Sigma-Aldrich Corp., Saint Louis, MO, USA) was used to extract WDP samples according to the method of Chen et al. [13]. Solid phase extraction columns containing $500 \mathrm{mg}$ of reversed phase octadecyl (Supelclean ENVI-18, Sigma-Aldrich Corp.) was activated by $5 \mathrm{~mL}$ of dichloromethane, $5 \mathrm{~mL}$ methanol and $5 \mathrm{~mL}$ ultra-pure water, respectively. Fifty $\mathrm{mL}$ methanol was added to the water sample $(1 \mathrm{~L})$ in order to improve the recovery. Then $1 \mathrm{~L}$ of DWP sample was percolated through the cartridges with a flow rate of $3 \mathrm{~mL} / \mathrm{min}$ under vacuum pump. After extraction, the PAHs trapped were eluted to a glass tube by $5 \mathrm{~mL}$ dichloromethane. The solvent fractions were then evaporated on a rotary evaporator, and exchanged by hexane to a final volume of $1 \mathrm{~mL}$.

Sediments were oven dried at $60^{\circ} \mathrm{C}$. Then the dry sediments were carefully collected, homogenized and passed through a $250 \mu \mathrm{m}$ standard sieve. The PAHs in sediment were extracted by ultrasonic-assisted solvent extraction according to the method by Chen et al. [13]. Sample preparation included homogeneous mixing of $2 \mathrm{~g}$ of sediment sample with $0.5 \mathrm{~g}$ anhydrous $\mathrm{Na}_{2} \mathrm{SO}_{4}$ to remove moisture and ultrasonication in $20 \mathrm{~mL}$ of dichloromethane for $1 \mathrm{~h}$ followed by centrifugation. Then $10 \mathrm{~mL}$ of supernatant was filtered through $3 \mathrm{~g}$ of

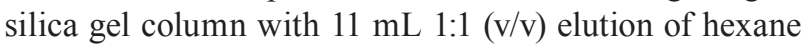
and dichloromethane. The solvent fractions were then evaporated on a rotary evaporator, and exchanged with hexane with a final volume of $1 \mathrm{~mL}$.

\section{Quality Assurance/Quality Control (QA/QC)}

The mean surrogate recoveries in WDP for anthracene-d10, pyrene-d10 and perylene-d12 were $89.3 \% \pm 4.3 \%, \quad 92.6 \% \pm 3.7 \%$ and $92.1 \% \pm 4.7 \%$ [mean $(\%) \pm$ relative standard deviation (\%)], respectively. In sediment samples the averaged recoveries for anthracene-d10, pyrene-d10 and perylene-d12 were $85.7 \% \pm 4.9 \%, \quad 90.2 \% \pm 6.7 \%$ and $100 \% \pm 5.4 \%$, respectively. After every 5 samples, a procedural blank and a spike sample consisting of all reagents was run to check for interference and cross contamination, and no interferences and cross contamination were found in the 
whole test process. The limit of detection (LOD) and limit of quantification (LOQ) were calculated as having signal-to-noise ratios of above 3 and 10, respectively, by seven replicate analyses. Blank assays were carried out and used for the calculation of LODs and LOQs. The LODs of 16 PAHs ranged from $0.02 \mathrm{ng} / \mathrm{L}$ for PYR to $0.1 \mathrm{ng} / \mathrm{L}$ for IcP in WDP and from $0.01 \mathrm{ng} / \mathrm{g}$ to $0.1 \mathrm{ng} / \mathrm{g}$ in sediment samples. The LOQs were in the range of 0.05-0.2 ng/L in DWP and 0.03-0.2 ng/g in sediment samples, respectively. Recoveries of 16 PAHs were in the range of $77.3-110 \%$ in WDP and $78.4-119 \%$ in sediment samples. The relative standard deviations (RSD) for the method were all below $5.0 \%$.

\section{Results and Discussion}

\section{PAHs in WDP}

The average concentrations of individual PAHs and $\sum$ PAHs (16 PAHs) in WDP from Weihe River were shown in Table 1. Samples with measured low concentration for one compound may have high concentrations for other compounds. The mean values of $\sum$ PAHs were $278.4 \mathrm{ng} / \mathrm{L}$ in 2015 and $108.6 \mathrm{ng} / \mathrm{L}$ in 2016. The average concentrations for 2-6-ring PAHs were 30.7, 75.1, 47.5, 55.1 and $69.7 \mathrm{ng} / \mathrm{L}$ in 2015, and were 18.44, 50.6, 15.8, 14.8 and $9.1 \mathrm{ng} / \mathrm{L}$ in 2016, respectively. Both in 2015 and 2016, 3-ring PAHs were abundant in WDP samples, representing on average $27.0 \%$ and $46.6 \%$ of all PAHs, respectively. And for individual $\mathrm{PAH}$, naphthalene and phenanthrene were dominant. The average concentrations of NAP and PHE in 2015 were $30.7 \mathrm{ng} / \mathrm{L}$ and $36.4 \mathrm{ng} / \mathrm{L}$, containing for $11.0 \%$ and $13.1 \%$, respectively. The average concentrations of NAP and PHE were $18.4 \mathrm{ng} / \mathrm{L}$ and $19.9 \mathrm{ng} / \mathrm{L}$ in 2016, containing for $16.9 \%$ and $18.3 \%$, respectively. The mean values of $\sum$ PAHs in upper reach was the highest. In 2015, the concentration of $\mathrm{BaP}$ in only five samples was lower than $2.8 \mathrm{ng} / \mathrm{L}$
(Environmental Quality Standard for surface Water of China, GB 3838-2002), suggesting water from Weihe River has a high health risk for drinking in 2015. But in $2016, \mathrm{BaP}$ concentration in only one sample $(3.3 \mathrm{ng} / \mathrm{L}$ in site 3) was higher than the limit value.

In most sites, $\sum$ PAHs concentration was as the following sequence: $2016<2015<2014$ (Fig. 2). For all I know three kinds of resarch [21-23] on PAHs pollution in Weihe River had been reported. However, only three individual PAHs (NAP, PHE and FLA) in WDP were studies in the two papers [21-22]. In order to interpret the tendency of PAHs pollution in Weihe River, the results of this study were compared with those from the two types of research and our previous study (Table 1). The average concentrations of NAP, PHE and FLA in WDP from Weihe River by Jiao [21] in 2009 were $179.7 \mathrm{ng} / \mathrm{L}, 588.4 \mathrm{ng} / \mathrm{L}$ and $179.6 \mathrm{ng} / \mathrm{L}$, respectively. The mean values of NAP, PHE and FLA for four sampling times by Lu [22] were $266.4 \mathrm{ng} / \mathrm{L}, 954.0 \mathrm{ng} / \mathrm{L}$ and $343.0 \mathrm{ng} / \mathrm{L}$, respectively. A direct comparison of our data to literature data is difficult due to difference in the number of samples, the sampling sites, the sampling season and the compounds considered among these studies. But to some extent the results showed that PAHs concentrations in Weihe River tended to decrease in recent years. The Weihe River Comprehensive Treatment Project has taken a series of measures, such as standardizing the discharge of industrial wastewater and domestic sewage along the Weihe River, strengthening the supervision of all pollution sources, and moving or closing down heavy polluting enterprises, which has reduced the total amount of pollutants from the source and has a significant effect on improving the water quality.

Compared with other polluted rivers in the world, the mean concentrations of $\sum$ PAHs $(278.4 \mathrm{ng} / \mathrm{L})$ in WDP from Weihe River in 2015 were much higher than those found in the Yellow River Delta in China (121 ng/L) [15], in Jinjiang River in China (53.2 ng/L) [17], in Soltan Abad River in Iran (142.06 ng/L) [25],

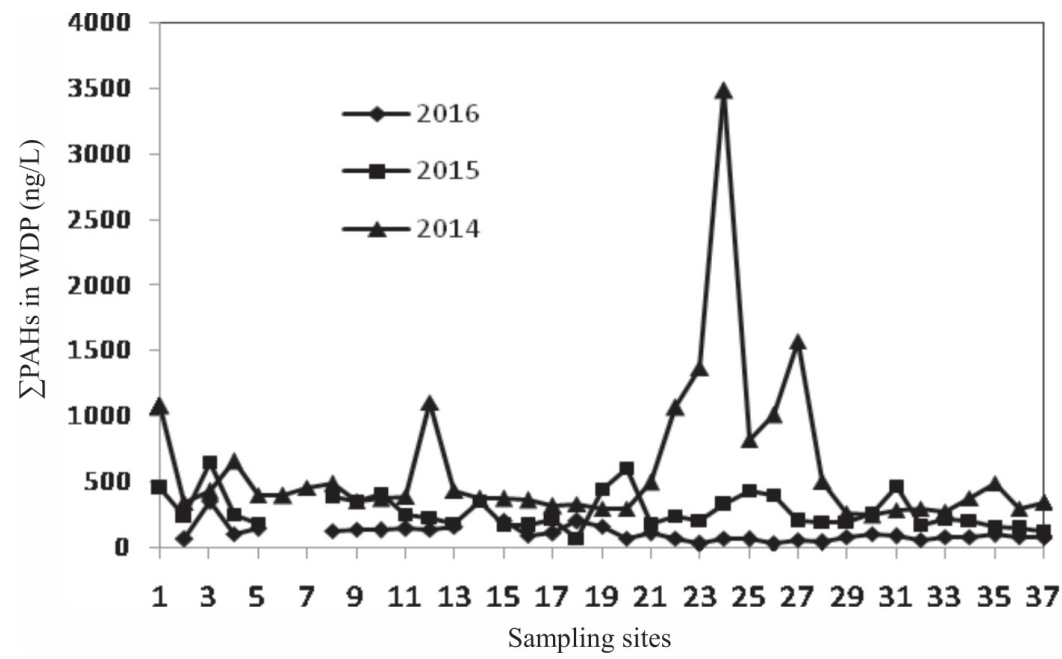

Fig. 2. Comparison of the $\Sigma$ PAHs mean value in WDP in 2015 and 2016 with that in $2014^{\mathrm{a}}$ from Weihe River. 
Table 1. The mean values of PAHs in WDP from Weihe River (ng/L).

\begin{tabular}{|c|c|c|c|c|c|c|c|c|}
\hline Sampling Time & Nov 2009a & Dec $2009^{b}$ & Mar 2010 & Jun $2010^{b}$ & Sep $2010^{b}$ & Aug $2014^{c}$ & Aug $2015^{\mathrm{d}}$ & Aug 2016 \\
\hline $\begin{array}{l}\text { Number of } \\
\text { Samples }\end{array}$ & 23 & 9 & 9 & 9 & 9 & 37 & 35 & 35 \\
\hline NAP & 179.7 & 131.2 & 913.9 & 30.7 & ND & 188.6 & 30.7 & 18.4 \\
\hline $\mathrm{ACY}$ & - & - & - & - & - & 7.3 & 2.3 & 9.4 \\
\hline $\mathrm{ACE}$ & - & - & - & - & - & 23.5 & 12.0 & 11.3 \\
\hline FLU & - & - & - & - & - & 45.9 & 21.2 & 8.7 \\
\hline PHE & 588.4 & 778.2 & 2144 & 483.3 & 413 & 57.8 & 36.4 & 19.9 \\
\hline ANT & - & - & - & - & - & 5.8 & 3.2 & 1.3 \\
\hline FLA & 179.6 & 19.4 & 211.1 & 1112 & 29.4 & 16.8 & 15.3 & 6.2 \\
\hline PYR & - & - & - & - & - & 18.5 & 13.0 & 4.8 \\
\hline $\mathrm{BaA}$ & - & - & - & - & - & 15.4 & 7.5 & 1.5 \\
\hline CHR & - & - & - & - & - & 19.4 & 11.7 & 3.6 \\
\hline $\mathrm{BbF}$ & - & - & - & - & - & 38.4 & 24.2 & 10.8 \\
\hline $\mathrm{BkF}$ & - & - & - & - & - & 30.1 & 13.8 & 2.9 \\
\hline $\mathrm{BaP}$ & - & - & - & - & - & 36.9 & 17.1 & 1.1 \\
\hline $\mathrm{IcP}$ & - & - & - & - & - & 30.1 & 24.0 & 3.0 \\
\hline DhA & - & - & - & - & - & 21.4 & 26.9 & 2.2 \\
\hline $\mathrm{BgP}$ & - & - & - & - & - & 51.1 & 18.8 & 3.8 \\
\hline$\sum$ PAHs & 947.7 & 928.8 & 3269 & 1626 & 442.4 & 607.0 & 278.4 & 108.6 \\
\hline
\end{tabular}

$\mathrm{ND}=$ Not detected

$-=$ Not Available

${ }^{\mathrm{a}} \mathrm{Jiao}[21],{ }^{\mathrm{b}} \mathrm{Lu}[22],{ }^{\mathrm{c}}$ our previous study [23], ${ }^{\mathrm{d}}$ this study.

in Elbe and Weser Rivers in Germany (10-40 ng/L) [26] and in Danube River in Hungary (122.6 ng/L) [27]. However, the mean total concentrations of $\sum \mathrm{PAHs}$ in WDP were lower than those found in Sarno River (739 ng/L) (Italy) [3], in Henan Reach of Yellow River in China (662 $\mathrm{ng} / \mathrm{L})$ [14], in Chenab River in Pakistan (629.47 ng/L in summer; $744.39 \mathrm{ng} / \mathrm{L}$ in winter) [28], in Gomti River in India (10,330 ng/L) [29], in Almendares River in Cuba (2512.0 ng/L) [30] and in Cauca River in Colombia (2344.5 ng/L) [31]. These comparisons lead us to consider that the PAHs concentrations in WDP from Weihe River in 2015 were at a moderate level while those in $2016(108.6 \mathrm{ng} / \mathrm{L})$ were at a lower level compared with other rivers in the world.

\section{PAHs in Sediment}

Fig. 3 illustrates $\sum$ PAHs in sediment samples in the studied river. In 2016, $\sum$ PAHs ranged from 123.3 to $1567.0 \mathrm{ng} / \mathrm{g}$ dry weight (dw) with a mean value of $539.1 \mathrm{ng} / \mathrm{g} \mathrm{dw}$. And the detected concentrations were 6.7-83.3 ng/g dw for 2-ring PAHs, 87.4-777.0 ng/g dw for 3-ring PAHs, $18.8-490.0 \mathrm{ng} / \mathrm{g} \mathrm{dw}$ for 4-ring PAHs, 2.6-173.2 ng/g dw for 5-ring PAHs, and 1.2-105.6 ng/g $\mathrm{dw}$ for 6-ring PAHs, respectively. Two-six ring PAHs accounted for $5.4 \%, 56.6 \%, 25.2 \%, 8.2 \%$ and $4.7 \%$ of the concentration of PAHs, respectively. In 2015 PPAHs ranged from 856 to $8,096 \mathrm{ng} / \mathrm{g} \mathrm{dw}$ with a mean value of $1340 \mathrm{ng} / \mathrm{g} \mathrm{dw}$. The concentration ranges for 2-6 ring PAHs were 407.8-578.9 ng/g dw, 284.9-1430 ng/g dw, $66.3-3813 \mathrm{ng} / \mathrm{g} \mathrm{dw}, 40.3-1587 \mathrm{ng} / \mathrm{g} \mathrm{dw}$ and $35.8-687.3$ $\mathrm{ng} / \mathrm{g} \mathrm{dw}$, accounting for $29.4 \%, 27.2 \%, 25.9 \%, 11.3 \%$ and $6.2 \%$ of the concentration of PAHs, respectively. $\sum$ PAHs concentrations in sediment in 2015 were higher than those in 2016. The concentration of BaP ranged from 5.8 to $432.4 \mathrm{ng} / \mathrm{g} \mathrm{dw}$ with a mean value of $34.1 \mathrm{ng} / \mathrm{g} \mathrm{dw}$ in 2015. And the concentration of BaP ranged from 0.34 to $62.4 \mathrm{ng} / \mathrm{g}$ dw with a mean value of $16.0 \mathrm{ng} / \mathrm{g} \mathrm{dw}$ in 2016.

Compared with other polluted rivers in the world, the mean value of $\sum$ PAHs in sediment from Weihe River (539.1 ng/g in 2016 and 1,340 ng/g in 2015) were higher than those found in Guan River Estuary (China) (133 ng/g) [18], in Qiantang River (China) (313 ng/g) [13], in Tiber River (Italy) $(155.3 \pm 134.1 \mathrm{ng} / \mathrm{g})$ [2], in Danube River (Hungary) (170.0 ng/g) [31] and in Ibirité Reservoir (Brazil) (129.5 ng/g) [32]. Values higher than those found in this river were found in Tianjing River (China) (10,980 ng/g) [33], in Pearl River (China) (4892 ng/g) [12], in Prai River (Malaysia) (4357 ng/g) 


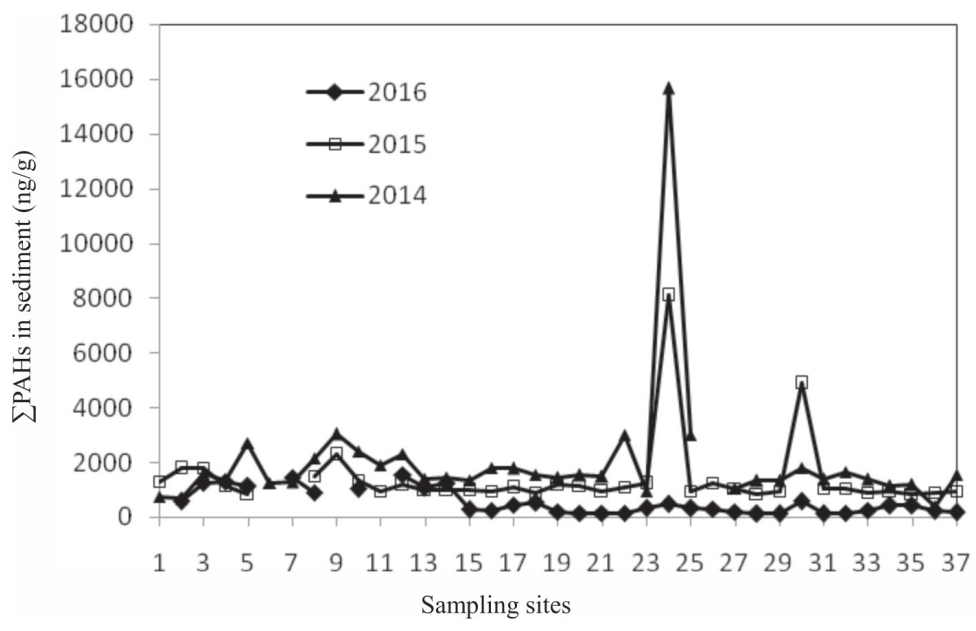

Fig. 3. Comparison of the $\Sigma$ PAHs mean value in sediment in 2015 and 2016 with that in 2014 [23] from Weihe River..

[4], in Mithi River (India) (2824.0 ng/g) [34] and in Ammer River (Germany) (8770.0 ng/g) [35]. The concentrations of PAHs in sediment from Weihe River were in a moderate level.

\section{The Spatial Distribution of PAHs}

The spatial distribution of PAHs in WDP and sediments were studied by comparing the concentrations of 2-6 rings PAHs among upper (sites 1-14), middle (sites 15-28) and lower (sites 29-37) reaches. The results were summarized in Fig. 4. It could be observed from Fig. 4a) and Fig. 4b) that both in 2015 and 2016, the highest concentrations of $\mathrm{PPAHs}$ in WDP were observed in upper reach, while the lowest concentrations of $\Sigma$ PAHs were found in lower reach. For sediment, the mean concentrations of $\sum$ PAHs in upper, middle and lower reaches were 1346, 1551 and $1390 \mathrm{ng} / \mathrm{g} \mathrm{dw}$
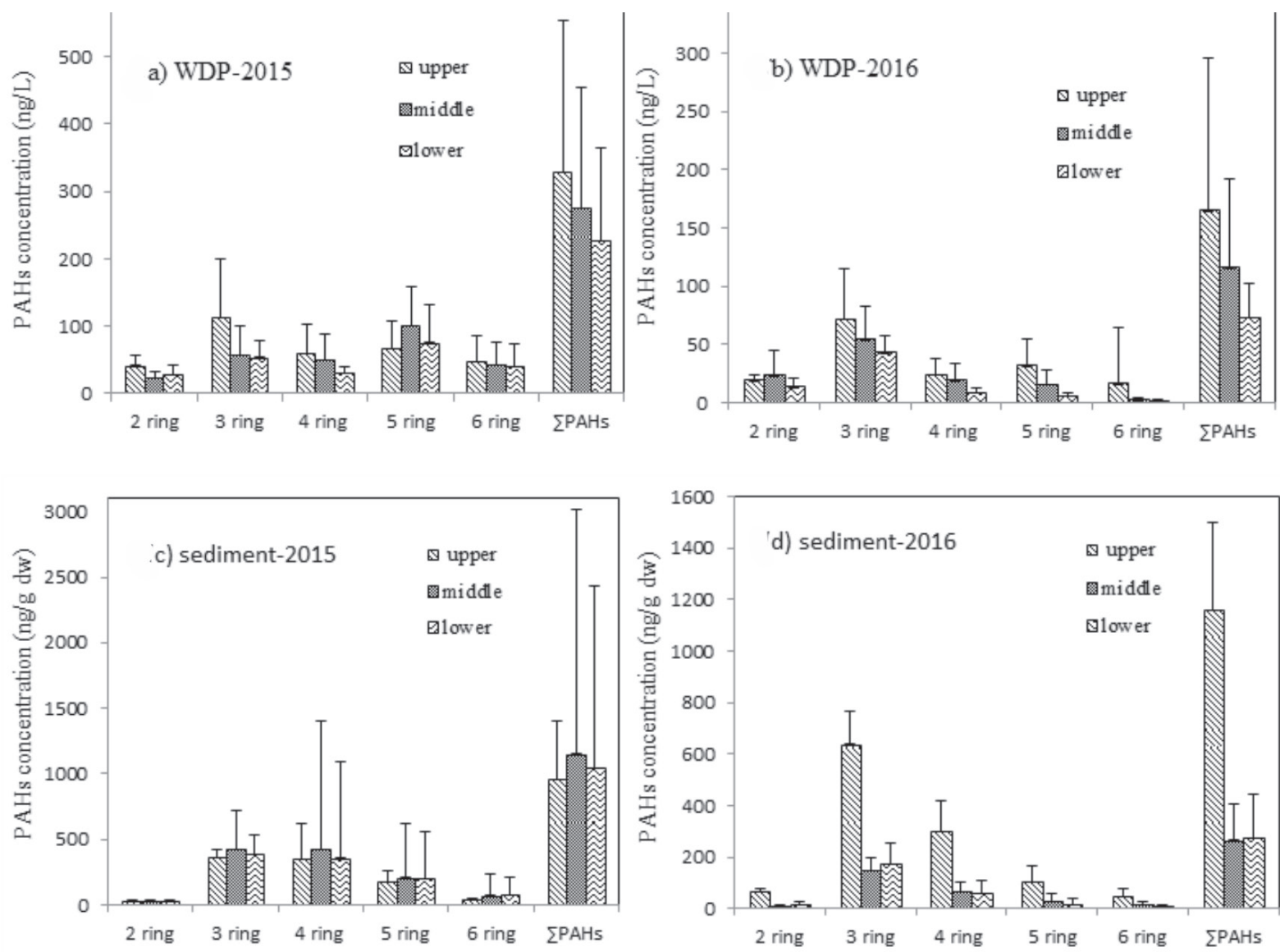

Fig. 4. The concentration of PAHs in upper, middle and lower reaches in Weihe River. 
Table 2. PAHs in sewage outlet discharging into Weihe River.

\begin{tabular}{|c|c|c|c|c|c|c|c|c|c|c|c|c|}
\hline & \multicolumn{8}{|c|}{ WDP (ng/L) } & \multicolumn{4}{|c|}{ Sediment (ng/g dw) } \\
\hline & W1 & W2 & W3 & W4 & W5 & W6 & W7 & W8 & W1 & W2 & W3 & W4 \\
\hline NAP & 122.6 & 128.4 & 88.4 & 193.2 & 94.1 & 74.9 & 94.1 & 77.7 & 366.8 & 457.1 & 396.8 & 311.6 \\
\hline $\mathrm{ACY}$ & 15.9 & 22.6 & 13.0 & 19.7 & 14.9 & 21.9 & 17.4 & 22.1 & 26.1 & 39.3 & 16.1 & 41.5 \\
\hline ACE & 28.4 & 30.2 & 23.7 & 20.7 & 13.0 & 12.8 & 18.3 & 15.5 & 139.0 & 141.9 & 136.5 & 128.6 \\
\hline FLU & 24.9 & 32.7 & 36.8 & 26.2 & 31.2 & 23.5 & 22.7 & 11.7 & 225.5 & 333.3 & 386.3 & 323.6 \\
\hline PHE & 120.1 & 103.2 & 113.3 & 165.4 & 99.6 & 79.2 & 77.2 & 81.0 & 491.2 & 493.4 & 364.2 & 298.1 \\
\hline ANT & 3.7 & 7.0 & 1.5 & 12.2 & 1.9 & 6.6 & 3.1 & 2.3 & 16.0 & 10.4 & 54.5 & 62.3 \\
\hline FLA & 17.1 & 14.5 & 16.2 & 20.5 & 17.8 & 17.0 & 13.1 & 29.0 & 124.3 & 99.4 & 355.9 & 124.0 \\
\hline PYR & 20.6 & 12.6 & 24.5 & 35.0 & 19.6 & 12.9 & 22.8 & 24.4 & 78.6 & 55.4 & 410.5 & 114.7 \\
\hline $\mathrm{BaA}$ & 9.1 & 9.6 & 9.4 & 11.8 & 12.4 & 29.5 & 14.8 & 13.0 & 24.0 & 12.2 & 262.5 & 44.7 \\
\hline CHR & 10.6 & 19.5 & 21.0 & 13.1 & 19.7 & 21.9 & 21.4 & 26.0 & 140.3 & 124.8 & 291.8 & 116.2 \\
\hline $\mathrm{BbF}$ & 33.4 & 46.9 & 37.3 & 43.5 & 27.1 & 21.5 & 21.3 & 18.1 & 66.2 & 50.8 & 238.0 & 65.8 \\
\hline $\mathrm{BkF}$ & 34.7 & 21.4 & 32.7 & 42.5 & 32.4 & 21.1 & 30.8 & 22.8 & 13.6 & 47.5 & 123.2 & 43.4 \\
\hline $\mathrm{BaP}$ & 20.8 & 31.3 & 40.6 & 30.9 & 23.0 & 30.6 & 30.7 & 31.3 & 52.0 & 24.2 & 214.6 & 85.1 \\
\hline IcP & 22.8 & 31.8 & 20.4 & 32.2 & 22.7 & 20.6 & 18.9 & 25.9 & 19.2 & 14.8 & 201.9 & 33.7 \\
\hline DhA & 23.5 & 15.7 & 20.6 & 40.8 & 31.5 & 21.3 & 20.6 & 18.2 & 25.1 & 23.8 & 50.9 & 20.7 \\
\hline $\mathrm{BgP}$ & 32.3 & 41.1 & 31.1 & 51.1 & 40.9 & 41.9 & 30.5 & 40.9 & 68.1 & 49.2 & 225.8 & 54.3 \\
\hline$\sum \mathrm{PAHs}$ & 540.7 & 568.6 & 530.5 & 759.0 & 502.1 & 457.1 & 457.7 & 459.8 & 1876.0 & 1977.7 & 3729.7 & 1868.4 \\
\hline
\end{tabular}

in 2015, and were $1158 \mathrm{ng} / \mathrm{g} \mathrm{dw}, 261.2 \mathrm{ng} / \mathrm{g} \mathrm{dw}$ and $282.8 \mathrm{ng} / \mathrm{g} \mathrm{dw}$ in 2016, respectively. Fig. 4c) and Fig. 4d) showed that the $\sum$ PAHs concentration in upper reaches in 2015 was closed to that in 2016. However, the concentration of $\sum$ PAHs in middle and lower reaches in 2016 were much lower than those in 2015. These results may be due to the following reasons. First, sediment in middle and lower reaches was dredged between the two sampling. Second, the branches of middle and lower Weihe River had lots of suspended particulate matter (SPM). PAHs would rapidly been associated with SPMs and then aggregated in sediment after them into the aquatic environment. In recent years, the water quality of these branches continued to improve and the concentration of PAHs decreased. At last, the diluting effect of tributaries of middle and lower Weihe River on main stream lead to this phenomenon.

\section{PAHs in Sewage Outlet Discharging into Weihe River}

The mean levels of $\sum$ PAHs in 8 WDP samples (W1-W8 in Fig. 1) from treated sewage outlets discharging into Weihe River ranged from 457.1 to $759.0 \mathrm{ng} / \mathrm{L}$, these $\sum$ PAHs concentrations were all much higher than those in Weihe River in 2016 (Table 2). The W1-W8 sites located in 8 wastewater outlets which flew through industrial gardens and received massive discharge and domestic sewage. But because the discharges of these outlets were small compared with the volume of runoff of Weihe River, they did not cause obvious influence on the level of PAHs of the main channel of Weihe River.

The sediment in W5-W8 could not been got. The $\sum$ PAHs concentrations in sediment from W1-W4 were 1876.0, 1977.7, 3729.7 and $1868.4 \mathrm{ng} / \mathrm{g}$, respectively. The highest $\sum$ PAHs concentration in sediment in Weihe River in 2016 was $1567.0 \mathrm{ng} / \mathrm{g}$ (in site 3), which was lower than those in each sediment from W1-W4.

\section{The Role of Total Organic Carbon (TOC) in Sediment}

It is believed that the organic matter in sediments generally plays an important role in controlling the distribution of many organic pollutants. Positive linear relations have been found between PAH concentrations and the TOC in sediment $[3,14]$. The TOC of sediments in Weihe River ranged from $0.86 \%$ to $3.8 \%$ in 2016 and $0.91 \%$ to $8.1 \%$ in 2015 . However, no positive linear relation was found between individual PAH concentration or $\Sigma$ PAHs and TOC in this study. In fact, a negative linear relation also exists between total PAH concentration and TOC contents in sediments as indicated by some other studies [36]. It is probable that, when TOC content is low, the sorption of PAHs 
Table 3. Rotated component loadings of principal components (PCs) for PAH compositions in the sediments of Weihe River.

\begin{tabular}{|c|c|c|c|c|c|c|c|}
\hline \multirow{2}{*}{ PAHs } & \multicolumn{4}{|c|}{ In 2015} & \multicolumn{3}{|c|}{ In 2016} \\
\hline & $\mathrm{F}_{1}$ & $\mathrm{~F}_{2}$ & $\mathrm{~F}_{3}$ & $\mathrm{~F}_{4}$ & $\mathrm{~F}_{1}$ & $\mathrm{~F}_{2}$ & F3 \\
\hline NAP & 0.595 & -0.176 & 0.076 & 0.678 & 0.508 & -0.264 & 0.572 \\
\hline $\mathrm{ACY}$ & 0.797 & -0.316 & -0.027 & -0.141 & 0.61 & -0.162 & 0.195 \\
\hline $\mathrm{ACE}$ & 0.770 & -0.33 & -0.23 & 0.446 & 0.664 & -0.465 & 0.413 \\
\hline FLU & 0.873 & -0.317 & -0.108 & 0.273 & 0.572 & -0.602 & 0.445 \\
\hline PHE & 0.880 & -0.121 & 0.214 & -0.155 & 0.715 & -0.402 & -0.115 \\
\hline ANT & 0.769 & -0.256 & 0.03 & -0.373 & 0.588 & -0.562 & 0.148 \\
\hline FLA & 0.918 & -0.067 & 0.075 & -0.253 & 0.78 & -0.24 & -0.303 \\
\hline PYR & 0.820 & -0.043 & 0.084 & -0.139 & 0.775 & -0.193 & -0.391 \\
\hline $\mathrm{BaA}$ & 0.407 & 0.764 & -0.192 & -0.079 & 0.669 & 0.293 & -0.298 \\
\hline $\mathrm{CHR}$ & 0.658 & 0.607 & -0.032 & -0.205 & 0.55 & 0.738 & -0.083 \\
\hline $\mathrm{BbF}$ & 0.234 & 0.786 & 0.121 & -0.164 & 0.798 & 0.667 & -0.332 \\
\hline $\mathrm{BkF}$ & 0.156 & 0.705 & -0.022 & 0.102 & 0.621 & 0.243 & -0.375 \\
\hline $\mathrm{BaP}$ & 0.267 & 0.669 & -0.358 & 0.124 & 0.18 & 0.639 & 0.048 \\
\hline IcP & 0.057 & 0.165 & 0.866 & 0.122 & 0.393 & 0.853 & 0.287 \\
\hline DhA & 0.058 & 0.387 & 0.596 & 0.23 & 0.375 & 0.854 & 0.289 \\
\hline $\mathrm{BgP}$ & 0.104 & 0.722 & -0.153 & 0.305 & 0.37 & 0.857 & 0.291 \\
\hline Explained variance (\%) & 37.5 & 22.8 & 9.0 & 7.9 & 35.6 & 28.3 & 10.1 \\
\hline
\end{tabular}

to sediments will be affected by both organic matter content and the inorganic matrix (e.g. clay minerals) [36].

\section{Source Apportionment of PAHs in Weihe River}

Principal component analysis is a suitable tool to identify the profiles of PAH sources. PCA represents the total variability of the original $\mathrm{PAH}$ data in a minimum number of factors. Factor scores of PCAs for each sample are then used to calculate the contribution percent of the major sources [37]. The results of PCA analysis of $\mathrm{PAH}$ concentrations in Weihe River are presented in Table 3.

In 2015 four principal components (PCs) were extracted for the samples (Table 3). The four factors were $37.5 \%, 22.8 \%, 9.0 \%$ and $7.9 \%$, respectively. Factor lwas heavily weighted by 3-4 ring PAHs accounted for the high loadings above $37.5 \%$. According to literature $[38,39]$, factor 1 can represent coal combustion. Factor 2 was predominately weighted by $4-5$ ring PAHs. The loading of 5 ring $\mathrm{PAHs}$ such as $\mathrm{BbF}$ and $\mathrm{BkF}$ was high. Elevated levels of $\mathrm{BbF}$ relative to other PAHs was suggested to indicate gasoline [40]. Therefore, factor 2 can represent gasoline combustion. Factor 3 was predominately weighted by $\mathrm{DhA}$ (5 ring) and $\mathrm{IcP}(6$ ring). IcP was suggested to indicate diesel [41-
42]. Thus, factor 3 can represent diesel combustion. Factor 4 was predominately weighted by low ring PAHs such as NAP, which suggested a petroleum related source [43].

In 2016 three principal components (PCs) were extracted for the samples (Table 3). The three factors were $35.6 \%, 28.3 \%$ and $10.1 \%$, respectively. According to literature [31-35], factor 1-3 represented coal combustion, diesel combustion and petroleum related source, respectively. From Table 3, both in 2016 and in 2015 , the most important source was coal combustion, which accorded with the energy structure in this area. Coal is still the main energy resource in Weihe River basin at the present, although its proportion is reducing. However, the second important source in the two years was different. In 2016 the second important source was diesel combustion while in 2015 it was gasoline combustion.

\section{Potential Toxicity Assessment}

Ecological risk assessment was performed to evaluate the possibility of adverse ecological effect. A widely used assessment method is based on toxic equivalent factors (TEFs) [44]. Seven PAHs (BaA, $\mathrm{CHR}, \mathrm{BbF}, \mathrm{BkF}, \mathrm{BaP}, \mathrm{IcP}, \mathrm{DhA}$ ) were considered as toxic PAHs due to their mutagenic and carcinogenic characteristics. Among the seven PAHs, BaP is the only 


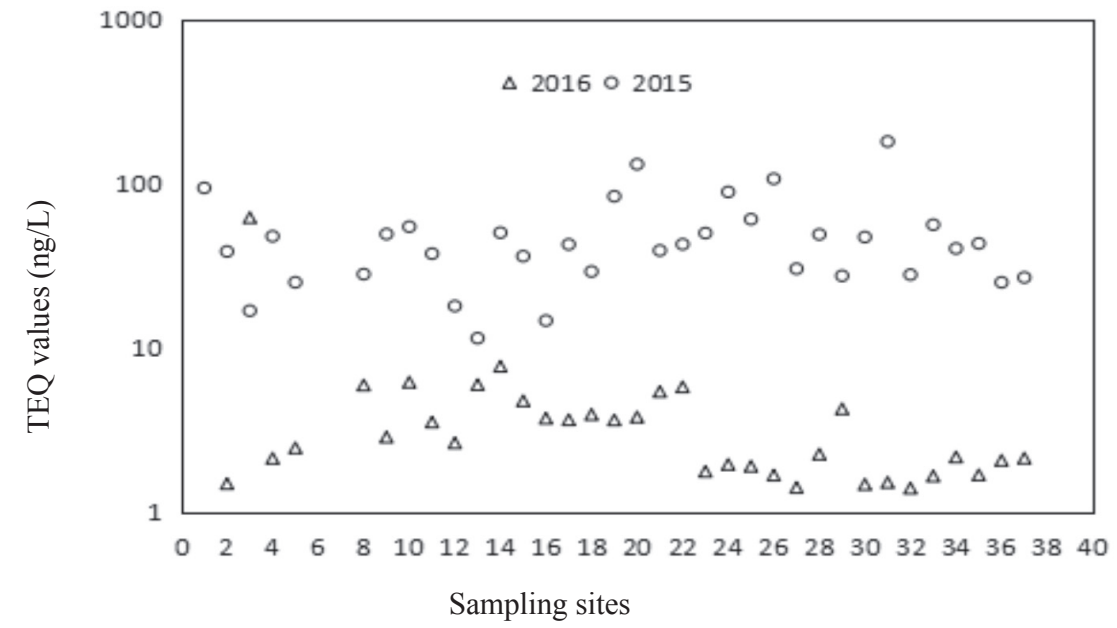

Fig. 5. Total TEQ values in different sites of Weihe River and its Estuary.

one having sufficiently toxicological data for derivation of a carcinogenic factor [2]. The limited value of $\mathrm{BaP}$ $(2.8 \mathrm{ng} / \mathrm{L})$ has been established in Environmental Quality Standard for Surface Water of China (GB3838-2002). TEFs for BaA, CHR, BbF, BkF, BaP, IcP, and DhA were $0.1,0.001,0.1,0.01,1,0.1$ and 1 , respectively [45]. The toxic equivalent quantity (TEQ) in each site was calculated based on the following equation:

$$
\begin{gathered}
\mathrm{TEQ}=\mathrm{C}_{\mathrm{BaA}} \times 0.1+\mathrm{C}_{\mathrm{CHR}} \times 0.001+\mathrm{C}_{\mathrm{BbF}} \times 0.1 \\
\quad+\mathrm{C}_{\mathrm{BkF}} \times 0.01+\mathrm{C}_{\mathrm{BaP}}+\mathrm{C}_{\mathrm{IcP}} \times 0.1+\mathrm{C}_{\mathrm{DhA}}
\end{gathered}
$$

...where $\mathrm{C}$ is the the carcinogenic $\mathrm{PAH}$ concentration in WDP (ng/L) .

Total TEQ values in different sites of Weihe River and its Estuary in 2015 and 2016 have been shown in Fig. 5. In 2015 the TEQ values in WDP of Weihe River were in the range of $11.4 \mathrm{ng} / \mathrm{L}$ to $179.3 \mathrm{ng} / \mathrm{L}$ with the mean value of $48.8 \mathrm{ng} / \mathrm{L}$ which was much higher than $2.8 \mathrm{ng} / \mathrm{L}$. And the exceeding standard rates was $100 \%$. In 2016 the TEQ values in WDP in Weihe River ranged from $1.4 \mathrm{ng} / \mathrm{L}$ to $61.7 \mathrm{ng} / \mathrm{L}$ with the mean value of $4.9 \mathrm{ng} / \mathrm{L}$ which was higher than $2.8 \mathrm{ng} / \mathrm{L}$, too. And the exceeding standard rates was $45.7 \%$. Compared with the results of previous research [23], the TEQ values in WDP decreased obviously, suggesting the health risk was decreasing in these years, too. However, these data indicated that PAHs were likely posing a serious risk for drinking.

\section{Conclusion}

This study provided very useful information for the evaluation of trace PAHs in river located in arid and semi-arid region in northwest China. Compared with other rivers in the world, the PAHs concentrations in WDP and sediment from Weihe River were at a moderate level. The result of principal component analysis indicated that coal combustion was the major sources, which accorded with the fact that coal was still the main energy resource in this area, although its proportion is reducing. The PAHs concentrations and risk in Weihe River were decreasing in recent years. With the carrying forward of WRCTP, some energy and chemical enterprises were shut down and moved from this area, which caused the reducing of many contamination indexes including PAHs in Weihe River. In brief, WRCTP played its role effectively in reducing PAHs pollution.

According to the results of this study and other published data, coal combustion, diesel combustion and petroleum related source were the three main sources of PAHs in many bodies of water around the world. So a substitution of traditional energies by clean energies in industrial production should be recommended to reduce PAH emission and further assure the health of local residents. PAHs' behavior, transport, fate and environmental risk to ecological systems have been extensively studied, however, more attention should been paid to PAHs pollution in underdeveloped areas. Making accurate calculations of the input and output fluxes of PAHs and controlling PAHs pollution are still very difficult. Government officials should not only emphasize GDP growth, but also attach importance to environmental protection, and for environmental engineers should develop theories and devices that could fight environmental problems.

\section{Acknowledgements}

The research was supported by National Natural Science Funds of China (Grant No.41302206), Provincial Natural Science Foundation of Shaanxi Province, China (No.2018JM4039) and the Fundamental Research Funds for the Central Universities, CHD (300102299205). 


\section{Conflict of Interest}

The authors declared that they have no conflicts of interest to this work. We declare that we do not have any commercial or associative interest that represents a conflict of interest in connection with the work submitted

\section{References}

1. WHO-Guidelines For Indoor Air Quality: Selected Pollutants-Polycyclic Aromatic Hydrocarbons. pp. 289, 2010.

2. MONTUORI P., AURINO S., GARZONIO F., SARNACCHIARO P., NARDONE A., TRIASSI M. Distribution, sources and ecological risk assessment of polycyclic aromatic hydrocarbons in water and sediments from Tiber River and estuary, Italy. Sci Total Environ, 566-567, 1254, 2016.

3. MONTUORI P., TRIASSI M. Polycyclic aromatic hydrocarbons loads into the Mediterranean Sea: Estimate of Sarno River inputs. Mar Pollut Bull, 64, 512, 2012.

4. KESHAVARZIFARD M., ZAKARIA M.P., HWAI T.S., YUSUFF F.M., MUSTAFA S., VAEZZADEH V., MAGAM S.M., MASOOD N., ALKHADHER S.A.A., FATEMEH A.J. Baseline distributions and sources of polycyclic aromatic hydrocarbons (PAHs) in the surface sediments from the Prai and Malacca Rivers, Peninsular Malaysia. Mar Pollut Bull, 88, 366, 2014.

5. TAHBOUB Y.R., ZAATER M.F., KHATER D.F. Semivolatile organic pollutants in Jordanian surface water. Arab J Chem, 10, S3318, 2017.

6. HADIBARATA T., YSAFIUDDIN A, GHFAR A.A. Abundance and distribution of polycyclic aromatic hydrocarbons (PAHs) in sediments of the Mahakam River. Marine Pollution Bulletin, 149, 110650, 2019.

7. EREMINA N., PASCHKE A., MAZLOVA E.A., SCHÜÜRMANN G. Distribution of polychlorinated biphenyls, phthalic acid esters, polycyclic aromatic hydrocarbons and organochlorine substances in the Moscow River, Russia. Environ Pollut, 210, 409, 2016.

8. VANE C.H., HARRISON I., KIM A.W. Assessment of Poly aromatic hydrocarbons (PAHs) and polychlorinated biphenyls (PCBs ) in surface sediments of the Inner Clyde Estuary,UK. Sci Total Environ, 54 (8), 1301, 2007.

9. KIM A.W., VANE C.H., MOSS-HAYES V., ENGELHART S.E., KEMP A.C. PAH, PCB, TPH and mercury in surface sediments of the Delaware River Estuary and Delmarva Peninsula, USA. Mar Pollut Bull, 129 (2), 835, 2018.

10. SOUZA M.R.R., SANTOS E., SUZARTE J.S., CARMO L.O., FRENA M., DAMASCENO F.C., ALEXANDRE M.R. Concentration, distribution and source apportionment of polycyclic aromatic hydrocarbons (PAH) in Poxim River sediments, Brazil. Mar Pollut Bull, 127, 478, 2018.

11. KHUMAN S.N., CHAKRABORTY P., CINCINELLI A., SNOW D., KUMAR B. Polycyclic aromatic hydrocarbons in surface waters and riverine sediments of the Hooghly and Brahmaputra Rivers in the Eastern and Northeastern India. Sci Total Environ, 636, 751, 2018.

12. MAI B.X., FU H.M., SHENG G.Y., KANG Y.H., LIN Z., ZHANG G., MIN Y.S., ZENG E.Y. Chlorinated and polycyclic aromatic hydrocarbons in riverine and estuarine sediments from Pearl River Delta, China. Environ Pollut, 117, 457, 2002.

13. CHEN Y., ZHU L., ZHOU R. Characterization and distribution of polycyclic aromatic hydrocarbon in surface water and sediment from Qiantang River, China. J Hazard Mater, 141, 148, 2007.

14. SUN J.H., WANG G.L., CHAI Y., ZHANG G., LI J., FENG J. Distribution of polycyclic aromatic hydrocarbons (PAHs) in Henan Reach of the Yellow River, Middle China. Ecotox Environ Safe, 72, 1614, 2009.

15. WANG L.L., YANG Z.F., NIU J.F., WANG J.Y. Characterization, ecological risk assessment and source diagnostics of polycyclic aromatic hydrocarbons in water column of the Yellow River Delta, one of the most plenty biodiversity zones in the world. J Hazard Mater, 169, 460, 2009.

16. MEN B., HE M., TAN L., LIN C., QUAN X. Distributions of polycyclic aromatic hydrocarbons in the Daliao River Estuary of Liaodong Bay, Bohai Sea (China). Mar Pollut Bull, 58, 818, 2009.

17. YANG D., QI S., ZHANG Y., XING X., LIU H., QU C., LIU J., LI F. Levels, sources and potential risks of polycyclic aromatic hydrocarbons (PAHs) in multimedia environment along the Jinjiang River mainstream to Quanzhou Bay, China. Mar Pollut Bull, 76, 298, 2013.

18. HE X., PANG Y., SONG X., CHEN B., FENG Z., MA Y. Distribution, sources and ecological risk assessment of PAHs in surface sediments from Guan River Estuary, China. Mar Pollut Bull, 80, 52, 2014.

19. LIU F., NIU L., CHEN H., LI P., TIAN F., YANG Q. Seasonal changes of polycyclic aromatic hydrocarbons in response to hydrology and anthropogenic activities in the Pearl River estuary, China. Mar Pollut Bull, 117, 255, 2017.

20. NIU S., DONG L., ZHANG L., ZHU C., HAI R., HUANG Y. Temporal and spatial distribution, sources, and potential health risks of ambient polycyclic aromatic hydrocarbons in the Yangtze River Delta (YRD) of eastern China. Chemosphere, 172, 72, 2017.

21. JIAO L. Study on Determination of Exogenous Environment Endocrine Disruptors in Weihe River Basin. Dissertation, Xi'an University of Architecture and Technology, China, 2010.

22. LU P. Determination and Analysis of Environmental Endocrine Disrupting Chemicals in Trunk Stream and Tributaries of Wei-he River in Xi'an. Dissertation, Chang'an University, China, 2012.

23. CHEN Y., JIA R., YANG S. Distribution and Source of Polycyclic Aromatic Hydrocarbons (PAHs) in Water Dissolved Phase, Suspended Particulate Matter and Sediment from Weihe River in Northwest China. Int J Environ Res Public Health, 12, 14148, 2015.

24. ZHAO C., WANG X., MA H., ZHANG L. Runoff simulation approach as a framework for mitigation of $\mathrm{COD}_{\mathrm{Cr}}$ pollution loading in Weihe Basin. $\mathrm{J}$ Arid Land Resour Environ, 24,164. 2010 [In Chinese].

25. KAFILZADEH F. Distribution and sources of polycyclic aromatic hydrocarbons in water and sediments of the Soltan Abad River, Iran. Egypt J Aquat Res, 41, 227, 2015.

26. SIEMERS A.K., MÄNZ, J.S., PALM W.U., RUCK W.K Development and application of a simultaneous SPEmethod for polycyclic aromatic hydrocarbons (PAHs), alkylated PAHs, heterocyclic PAHs (NSO-HET) and phenols in aqueous samples from German rivers and the North Sea. Chemosphere, 122, 105114, 2015.

27. NAGY A.S., SZABó J., VASS I. Occurrence and distribution of polycyclic aromatic hydrocarbons in 
surface water and sediments of the Danube River and its tributaries, Hungary. J Environ Sci Health A-Tox Hazard Subst Environ Eng, 49 (10), 1134, 2014.

28. FAROOQ S., EQANI S.A., MALIK R.N., KATSOYIANNIS A., ZHANG G., ZHANG Y., LI J., XIANG L., JONES K.C., SHINWARI Z.K. Occurrence, finger printing and ecological risk assessment of polycyclic aromatic hydrocarbons (PAHs) in the Chenab River, Pakistan. J Environ Monit, 13, 3207, 2011.

29. MALIK A., VERMA P., SINGH A.K., SINGH K.P. Distribution of polycyclic aromatic hydrocarbons in water and bed sediments of the Gomti River, India. Environ Monit Assess, 172 (1-4), 529, 2011.

30. SANTANA J.L., MASSONE C.G., VALDéS M., VAZQUEZ R., LIMA L.A. OLIVARES-RIEUMONT S. Occurrence and source appraisal of polycyclic aromatic hydrocarbons (pahs) in surfacewaters of the Almendares River, Cuba. Arch Environ Contam Toxicol, 69 (2), 143, 2015.

31. SARRIA-VILLA R., OCAMPO-DUGQUE W., PáEZ M., SCHUHMACHER M. Presence of PAHs in water and sediments of the Colombian Cauca River during heavy rain episodes, and implications for risk assessment. Sci Total Environ, 540, 455, 2016.

32. MOZETO A.A., YAMADA T.M., DE MORAIS C.R., DO NASCIMENTO M.R., FADINI P.S., TORRES R.J., SUEITT A.P., DE FARIA B.M. Assessment of organic and inorganic contaminants in sediments of an urban tropical eutrophic reservoir. Environ Monit Assess, 186 (2), 815, 2014.

33. SHI Z., TAO S., PAN B., FAN W., HE X.C., ZUO Q., WU S.P., LI B.G., CAO J., LIU W.X. Contamination of rivers in Tianjin, China by polycyclic aromatic hydrocarbons. Environ Pollut, 134, 97, 2005

34. SINGARE P.U. Studies on polycyclic aromatic hydrocarbons in surface sediments of Mithi River near Mumbai, India: assessment of sources, toxicity risk and biological impact. Mar Pollut Bull, 101 (1), 232, 2015.

35. LIU Y., BECKINGHAM B., RUEGNER H., LI Z., MA L., SCHWIENTEK M., XIE H., ZHAO J., GRATHWOHL P. Comparison of sedimentary PAHs in the rivers of Ammer
(Germany) and Liangtan (China): differences between early- and newly-industrialized countries. Environ Sci Technol, 47 (2), 701, 2013.

36. ZHU L., CHEN Y., ZHOU R. Distribution of polycyclic aromatic hydrocarbons in water, sediment and soil in drinking water resource of Zhejiang Province, China. J Hazard Mater, 150, 308, 2008.

37. LI B., FENG C., LI X., CHEN Y., NIU J., SHEN Z. Spatial distribution and source apportionment of PAHs in surficial sediments of the Yangtze Estuary, China. Mar Pollut Bull, 64, 636, 2012.

38. LI C.K., KAMENS R.M. The use of polycyclic aromatic dydrocarbons as source signatures in receptor modeling. Atmos Environ, 27 (4), 523, 1993.

39. ROGGE W.F., HILDEMANN L.M., MAZUREK M.A. Sources of fine organic aeroso. 2. Non catalyst and catalyst-equipped automobiles and heavy-duty diesel trucks. Environ Sci Technol, 27 (4), 636, 1993.

40. HARRISON R.M., SMITH D.J.T. Source apportionment of atmosphere polycyclic aromatic hydrocarbons collected from an urban location in Birmingham, UK. Environ Sci Technol, 30, 825, 1996.

41. SIMCIK M.F., EISENREICHS J., LIOY P.J. Source apportionment and source/sink relationships of PAHs in the coastal atmosphere of Chicago and Lake Michigan. Atmos Environ, 33, 5071, 1999.

42. ABRAJANO T.A., YAN B., O'MALLEY V. Higher molecular weight petrogenic and pyrogenic hydrocarbons in aquatic environment. In Treatise on Geochemistry, 2nd ed.; Sherwood Lollar, B., Ed., Elsevier: Amsterdam, Netherlands, 11, 481, 2014.

43. DUODU G.O., OGOGO K.N., MUMMULlAGE S., HARDEN F., GOONETILLEKE A., AYOKO GA. Source apportionment and risk assessment of PAHs in Brisbane River sediment. Australia. Ecol Indic, 73, 784, 2017.

44. NISBET I.C.T., LAGOY P.K. Toxic equivalency factors (TEFs) for Polycyclic aromatic hydrocarbons (PAHs). Regul Toxicol Pharmacol, 16 (3), 290, 1992.

45. Environmental Protection Agency, 40 CFR Part 423, Appendix A, 2012. 
